\title{
Evolution of Chestnut Illustrations in Works of XVI Century - A Contribution to the History of Botany
}

\author{
Andreia Marlise Carneiro de Carvalho ${ }^{1}$ e Isilda Teixeira Rodrigues ${ }^{2}$ \\ ${ }^{1}$ Student of PhD in Earth Sciences and Life of Universityof Trás-os-Montes and Alto \\ Douro.Universityof Trás-os-Montes and Alto Douro, Vila Real, Portugal. \\ ${ }^{2}$ Depart. Education and Psychology, Vila Real, Portugal. Research of CIIE - Centre for Research and \\ Educational Intervention, University of Psychology and Educational Sciences, University of Porto, \\ Porto, Portugal. \\ ${ }^{1}$ andreiamcc_500@hotmail.com, ${ }^{2}$ isilda@utad.pt
}

\begin{abstract}
This study integrated a broader research and had as main objectives: a) to survey chestnut illustrations in works of the sixteenth century; b) reflect on the importance of chestnut illustrations for the increase of the history of botany; c) reflect about the status of science history as a teaching tool in science education.
\end{abstract}

The chestnut existed around thousands years following the man from the Paleolithic. It was called bread tree, because in the Middle Ages, this tree was cultivated in several areas of the world and constituted a valuable resource for the sustainability of populations. This investigation used a quality methodology with the help of documentary analysis of several works of authors considered as references in XVI century.

It was found that since the sixteenth century the authors had some knowledge of the morphological features of the different vegetative organs of sweet chestnut species, allowing the visualization and differentiation of root, stem, leaves and fruit.

Keywords:Botany; chestnut; illustrations; bread tree.

\section{INTRODUCTION}

The chestnut was introduced in Greece from Asia Minor, thence to the North and West (France, Germany, Great Britain), Ireland and subsequently passed to Italy, reaching the Iberian Peninsula, including Portugal [1]. Other researches commented that during the Roman Empire, these civilization bring together the knowledge of cultivating these specie for many European countries [2] [3].

Over the time the chestnut became a precious resource for mountains communities, and this tree has been considered the tree of life, providing food, the timber for carpentry, the fabrication of supporting poles for vineyards, as well as for heating purposes [4] [5].

The first images of plants date back four thousand years ago, originated in Mesopotamia and Egypt, where developed agricultural civilizations included images of plants on the walls of their temples [6].

Theophrastus (371 a. C - 286 a. C), one of the most important botanical inAntiquity andconsidered as"the father ofBotany," wrote two of the most influential works onBotanyof Antiquity:De historiaPlantarum and De causisPlantarum, published in 1483and1529respectively.It was consideredby some authors, indispensable guidesto understanding andteaching Botany. This botanicwas, consideredadvancedfor its time because of his innovative research, such asthe practice ofplantacclimatization, introduction of new technical terms, a distinction of forms of reproductionand inflorescences, andalsostudied the germination seedsofvarious species [7].

Dioscorides(?- 70 d. C.)greco-roman author, was considered one of the founders ofPharmacology and wrote the workDe MateriaMedicain 1478, in which described more than600plants withits medicinal properties, and somebotanicalrespectivedescriptions andillustrations[8].This workis considered thefirst illustratedHerbarium[7].

According to other researcher, in the XV and XVI century's the Botany developed as a scientific discipline, for this contributed several factors: the invention of printing; the appearance of the paper for the preparation of herbal; the development of botanical gardens and botanical expeditions. All 
these factors have enabledthe remarkable increasein the numberof known speciesand allowedthe dissemination oflocal or regionknowledgeon a global scale [8].

The history of botanical illustrations as a source of accurate and useful information about plants is generally considered to have begun in classical times, with the publication of the first known herbalsbooks describing the medicinal properties of plants. In the Renaissance, the herbals included accurate representations of plants drawn from nature [9].

The botanical illustrations provide valuable information about the different species of plants[9].

The illustration art is a tool for science and it provides international communication by creating a visual language to spread knowledge. The aim of botanical illustration is to record the plants and to trace a country's or region's flora [10]. Other author adds that illustrations allows representing a sample of a plant and these may be used by students or researches to identify that species in the field or to differentiate that plant from related species [9].

The scientific illustration appeared in the accounts of travelers, natural philosophers, who explored the unfamiliar territory over the centuries. The expeditions stimulated the development of drawing and painting, as it was required the faithful witness of the findings and to identify plants with potential use in pharmacology, chemistry and agriculture [11] [12]. For over two millennia plants were been reported in designs to make their identification easier and reliable [13].

Scientists allude that the scientific illustration was and still is a chart area that combines science and art in a single communication model [14].

The images are more attractive and easier to understand and they also contribute to better explain the written text [15].

In the illustrations, the type of trace, the use of color, the contrast of the picture and the design are basicelementsthat helpthe student inunderstanding the vision, conceptsand the structures. In addition, educational, conceptual, aesthetic and technical decisions on the representation and processing of information constitute the field of scientific illustration [16].

The sixteenth century botany illustrations demonstrate the importance of visual information in the pursuit of knowledge about the natural world. Early modern natural history was profoundly dependent on creation of images, many of them replicable by way of print, such us like drawings, could enable identification and, in turn, use or classification of what they represented [17].

The botanical illustration clarifies doubts, enables easier understanding and makes visible images formed from fragments. It's considered an investigative activity that requires mastery of specific techniques, like visual acuity and scientific knowledge [18].

Curiosity regarding the medicinal properties of plants was the humble origin of scientific botany [19]. Botanical illustration has been essential to botany since its inception as a modern science in the nineteen century, because the illustrations were more accurate and informative that the accompanying texts [20].

The study of the evolution of illustrations allows understanding the techniques used in the history of illustrated books for representation of images, the illustrations suffered various processes, e. g., illuminated manuscripts, woodcut and lithography. As a result of development and adaptation of new image and writing breeding techniques there was the increasing need to edit a larger number of volumes and consequently an intensification in the amount of readers. In each period it was used one or more different processes of illustration, its recognition as well as the reason for their choice has become important sources of study for History of Science. This information allowed us to understand what kind of knowledge was possessed by the scholars of each century and their evolution over the time, with all the social, religious and cultural pressures, that they have been subjected [12].

The use of illustrations to convey scientific information is very valuable,botanists knew that in order to be successful at transmission of scientific knowledge, is important to making botany an attractive science and keeping it a serious discipline [21].The value of scientific illustration is to enable the reader an easy comprehension of the written text [22]. Often in Natural Sciences, illustration enables immediate recognition of the physical characteristics of an organism, by color, shape, among other things, eliminating the need for a lot of text. 
Researchers of education area mention that the introduction of the History of Science in Science Education contributes to improve understanding of concepts developed by Science; it explains the historical, social, political and economic influences, as important for scientific development in a given historical moment [23]. Besides this the history of science can also help the students know the Science from another perspective, so that it becomes more attractive, awakening interest in scientific knowledge and as well in the discussions around Science [24]

The chestnut belongs to genus Castanea, what include several species, and in this study we will only address the European chestnut (Castanea sativa Mill.) and equine species (Castanea equine), originating from the Balkans and currently cultivated across Europe. The main distinction between these species of chestnut is that European chestnut presenting 2 to 3 fruits per hedgehog, with their nuts often used in foodstuffs. In other turn, the equine species presents only one chestnut for hedgehog. Their seeds, bark and leaves are used in medicine. The current classification of common chestnut, European species addressed in the related work is Castanea sativa Miller (1768) due to the English botanist Philip Miller (1691-1771). The species Castaneaequinaclassified by Charles l'Écluse in 1583 and more later was classified and named Aesculushippocastanum by Linnaeus in 1753 [25].

All this knowledge about the evolution of illustrations, including those related to the chestnut, may constitute, as already noted, a valuable contribution to the history of botany and a broader perspective for the History of Science in general. The study of the illustrations can later be used as a tool for the introduction of the History of Science in Science Education.

This paper is structured as follows: introduction, next abstract, the presentation of the methodology and the works that we used for this study then present the chestnut illustrations, with the respective analysis and description and finally the conclusions.

\section{Materials AND Methods}

A qualitative methodology was used in this research work, applying the documentary analysis of several works. The research wasmainlycarried outin primary sources, because they were more reliablerecords and also was used some secondary sources. Theworksused in thisstudywere:

- De historiastirpiumcommentariiinsignes(1551) of Leonhart Fuchs;

- Naturalishistoriaeopvsnovvm in qvotracta(1551) of Adam Lonicer;

- IndexDioscoridis(1558) of Amato Lusitano;

- New Kreüterbuch: Mit den allerschönstenvndartlichstenfigurenallergewech $\beta$, dergleichenvormals in keener sprachnie an tag kommen(1563) of Pietro Mattioli;

- Phytognomonica Io. BaptistaePortae(1589) of Giovanni Battista della Porta;

- Rariorumplantarum historia (1601) of Charles d'Écluse.

All of these works were part of the period deeply famous by great advances in the sciences - the Renaissance.This period of history was considered the period in European civilization that have been described by a surge of interest in classical learning, values and the opportunity to support creativity and change in Europe [26]. The Renaissance produced a golden age with many achievements in art, literature, and science and the rebirth of cultural and intellectual pursuits [27].

The illustrations by great botanicals in this era, contributed to the advancement of scientific knowledge in the field of Botany, about the different species of plants, and more particularly on the chestnut.

\section{RESUlTS AND DisCUSSION}

\section{Some considerations on the illustrations of chestnut found in the works of the sixteenth century}

In this section we state some considerations about the illustrations of the chestnut, found in some works of the sixteenth century.

The art of illustrating plants is an old one. The development of civilizations, contributed for some botanical illustrations, they can be described with the same detail as a scientific text. The first naturalists made their sketches in their own environment, they just used the vision, hand, pencil to record what observed, producing beautiful detailed boards, which currently represented true works of art [28]. 
Scientific illustrations can supplement the text, replacing it completely or supporting it by giving it a visual form [29].

ScientificNaturalismemergedin the Renaissanceand markedsignificantly theway of makingbotanical illustrations.Other author allude that scientific illustrationis the visualcomponentof Sciencesthat, in the sphere ofBotany,isdedicated to thevegetable kingdom, in other words, is the scientificdesign of theplant. It requiresfrom thedesignerthe samescientific curiosityfeaturingan investigator, leading him toresearch theguidanceof thebotanistswho studythe plant species, to meetthe elements ofplants thatareillustrating [18].

The sciences of botany and medicine, fostered by expeditions around the world, had included the art of the scientific illustration for some time [30].

Over timevariousauthors publishedchestnutillustrations.

Leonhart Fuchs(1501 - 1566), german doctor andbotanist,in his work De historiastirpiumcommentariiinsignes, publishedin 1551in Basileia, presentachestnutillustration (Figure 1). This work marked him as one of the first to use botanical nomenclature [31] andis best known today as one of the pioneers of accurate representations of plants in the history of scientific illustrations [32].

Observed the Figure1thatwas drawnin black andwhite andhas littledetail,butit is perceivedwith theserratedleaves and asymmetrical aspect,both are characteristics ofchestnut leavesand form partof theknowledge oftheir biologicalcharacterization. Furthermore, it isvisibleto the observerribson the foliage, demonstratingthe illustrator's abilityto representtheclosest to thetrueleaves(Figure1).

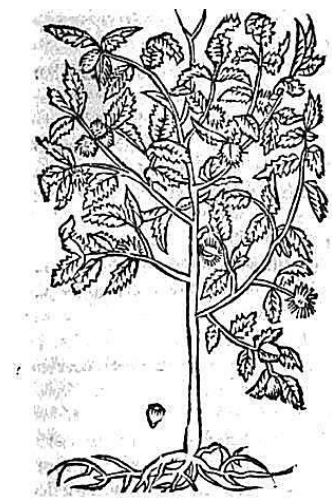

Figure1.Chestnut illustration in the work De historiastirpiumcommentariiinsignes [33].

Thehedgehogs weremade withprecision and werecovered withthorns. It isalsoobserved in this picture the chestnutrootsbut is notperceived the branchofsecondary rootsfrom theprimaryroot, one of their morphologicalfeatures (Figure 1).

Adam Lonicer(1528 - 1586), another german botanist, published inhis workNaturalis historiaeopvsnovvm in quotracta, printed in 1551in the city ofFrankfurt, a chestnutillustration. The image ofLonicer(Figure2) was published in the same year as the picture of Fuchs, butunlike the previous one,was presented in color and sonlyone branch of the tree and nottheoverall lookof the chestnut.

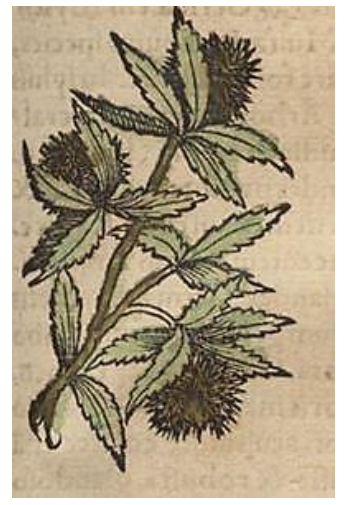

Figure2.Chestnut illustration in the work Naturalis historiaeopvsnovvm in qvotracta [34]. 
In this image (Figure 2)the leaves have a sawnformand fasciculate hedgehogs that constitute their real characteristics and this picture have greater level ofdetail than Fuchs. It also can observe the hedgehogs brown indicating its maturation stage, the green color of the leavesandthe fact that theauthor hasoutlined the catkins (flowers) of chestnut near the foliage, a characteristicappearance.However,catkinswere designedwith littlesingularitybecause isn't observed the glomeruli.

Amato Lusitano(1511 - 1568), a majorPortuguesedoctorin his workIndex Dioscoridis, published in 1558, inLeon, presents an illustrationofchestnut drawn black and white(Figure 3). This picture is similar toLeonhartFuchs published inNaturalis historiaeopvsnovvm in qvotractain 1551, both authorsmayhave been aware of each other's work or may haveused thesameillustrator.

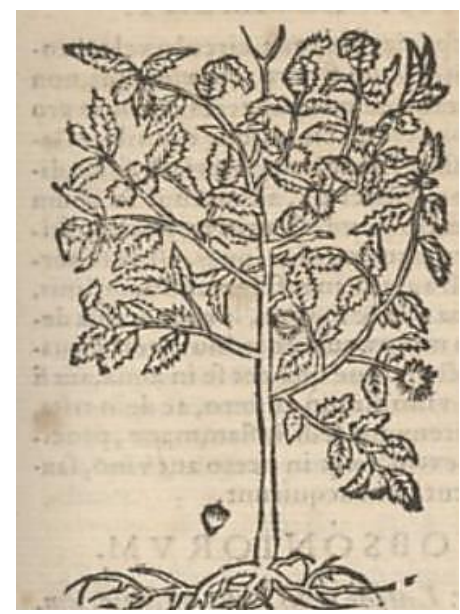

Figure3.Chestnut illustration in the work Index Dioscoridis [35].

The Italian naturalist Pietro Mattioli (1501 - 1577), by this time, publish the work New Kreüterbuch: Mit den allerschönstenvndartlichstenfigurenallergewech $\beta$, dergleichenvormals in keener sprachniean tag kommen, which was printed in Prague in 1563. This book presented a color illustration of the European chestnut.The Figure 4 presented one of the principal morphological leaves, which is toothed aspect. Hedgehogswere designedwith littledetail,butis visibletheircharacteristiccoatingthorns. We can still observe some catkins, and other flowers like dandelion, the latter out of context, because European chestnut has only its flowers on the edge of the branches in the form of clusters (catkins).

This illustration(Figure 4) is representative, but indistinct and a little bit confusing since all chestnut constituents are superimposed.

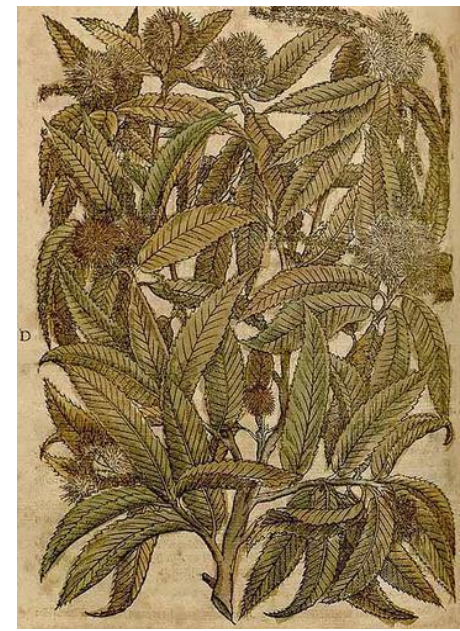

Figure4. Chestnut illustration in the work New Kreüterbuch: Mit den allerschönstenvndartlichstenfigurenallergewech $\beta$, dergleichenvormals in keener sprachniean tag kommen [36].

The physical and italian naturalist Giovanni Battista della Porta (1535 - 1615) in its work Phytognomonica Io, published in 1589 in the city of Frankfurt, displays a hand-drawn illustration of chestnut tree fruit (Figure 5). This figure arises after the Lonicer and was designed in black and white, unlike the previous image that was drawn with colors. 
This authorrepresents thenutswith great detail and observedtheelliptical, elongatedandbulky shape. The presenceof the shellto coverthe fruit, whichis smooth,leatheryand presentsgrooveandsplines.Theseaspectsarerelatedto the realmorphologicalcharacteristics ofbrown, revealing a painstaking workbyitsillustrator.

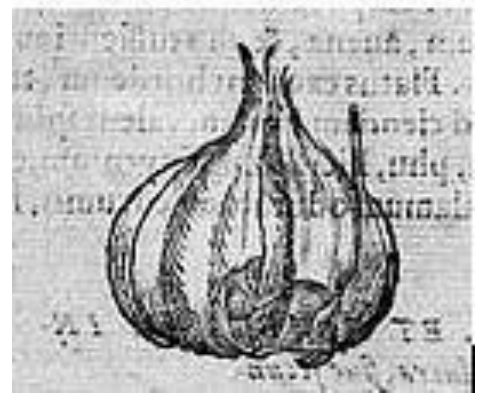

Figure5.Chestnut illustration of genus Castanea in the work Phytognomonica Io.Baptistae Portae [37].

Charles de l'Écluse(1525 - 1609) was a belgian doctor, considered one of the most influential botanists and horticulturist of the sixteenth century. Published in 1601, based on the work of the Conferences Simple, of medical and botanical Portuguese Garcia de Orta (1500-1568) an important treaty of Botany, RariorumPlantarumhistoria, illustrated with over a thousand engravings and group the species by its affinity.

Analyzing the illustration of Charles del'Écluse(Figure6), we detected the ribsof leavesareclearly evident. The leaves are opposite, with longpetioles, divided into5 to 7leafletstoothedvariablesizewideningthe apexand terminate inobtusetip, however in this image doesn't observe the catkins. Thisauthor alsopresents one of theurchinsof thissemi-open type,with manythorns. Thefruit isirregularly andrough, the morphologicalcharacteristicsrepresentedin this illustrationare distinct fromreality, because the nut isbulkyand has arounded shape.

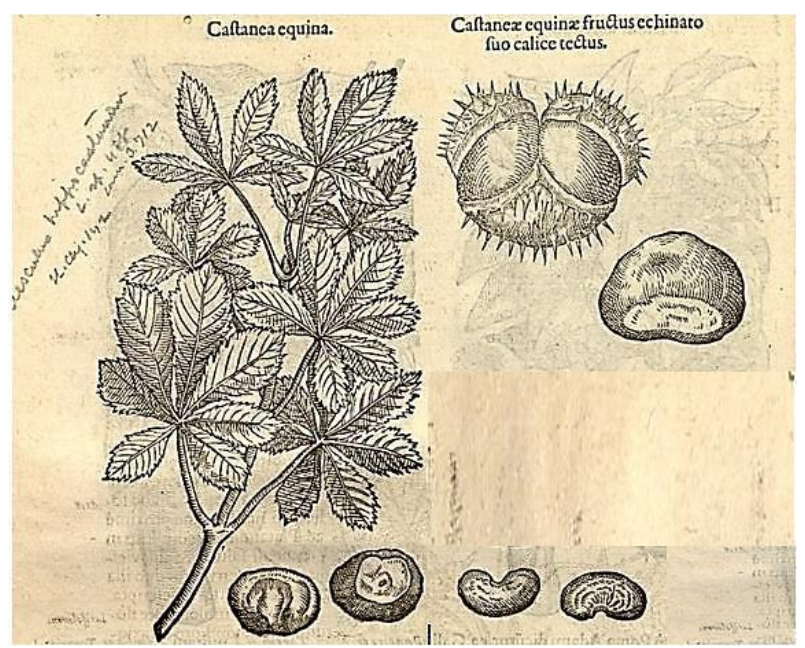

Figure6.Illustration of Castaneaequina in the work RariorumPlantarumhistoria [38].

\section{Conclusions}

Thisstudy contributed to better understand the evolution of the illustrations of the chestnut over time, they have been influenced by the different techniques of representation and the contributions of the various artistic currents that dominated the period ofhistoryin which they werecarried out.

The illustrators of the sixteenth century already had some knowledge about morphological features about the different vegetative organs of sweet chestnut species, allowing the visualization and differentiation of root, stem, leaves and fruit. Most of the sixteenth century graphics were performed coal, representing the chestnut in general and with little detail. Throughout the sixteenth century, the illustrations presented a greater number of constituent elements of the chestnut, gradually more complete and detailed. Of all the illustrations of the XVI century the most complete one was the illustration of Mattioli, which has a greater number of constituent elements of the chestnut, however, some illustrations of the same season showed different characteristics, such as the della Porta that only shows the outline of a chestnut. 
The illustrations can be used as a resource in science education and can also help students to better understand that throughout history. This research can help in the comprehension of how the plant evolved, depending on the degree of scientific development time and existing visual representation techniques and can also contribute to better understanding the evolution of scientific knowledge on the chestnut during the sixteenth century, and therefore the history of botany.

\section{REFERENCES}

[1] Lage, J., Castanea - Uma dádiva dos Deuses, 2ª ed.Braga: Paraíso do Livro.31-32 (2006).

[2] Conedera, M., Krebs, P., Tinner, W., Pradella, M. andTorrioni, D., The cultivation of Castanea sativa (Mill.) in Europe: from its origin to its diffusion on a continental scale, Vegetation History and Archaeobotany.13, 161-179 (2004).

[3] Conedera, M. and Krebs, P., History, present situation and perspective of chestnut cultivation in Europe,Proc. II ${ }^{\text {nd }}$ Iberian Chestnut Congress. Leuven, Belgium: ActaHorticulturae, 2008,ch. 1, pp. 23-27.

[4] Bounous, G., Italy - Historical background. In Following Chestnut Footprints (Castanea spp.). Cultivation and Culture, Folklore and History, Traditions and Uses, ScriptaHorticulturae (9), Italy: A.G.C. ArtiGraficheCiampino, 2009, ch. 14, pp. 73-84.

[5] Rodrigues, I. and Carvalho, A., Evolução das ilustrações do castanheiro do séc. XVI - um contributo para da história da botânica. Ata do XII Congresso da Sociedade Portuguesa de Ciências da Educação. Ciências da Educação: Espaços de investigação, reflexão e ação interdisciplinar, Portugal. (2014).

[6] Buck, J., A Brief History of Botanical art - Early portrayal of Plants - Part 1, The Botanical Artist, 15(1), (2012).

[7] Leitão, N., Os primeiros botânicos. Naturlink. (2001). Access 24 february 2016,<http:// naturlink.sapo.pt/Natureza-e-Ambiente/Interessante/content/Os-primeiros-botanicos? bl=1>

[8] Faria, M., A importância da disciplina Botânica: Evolução e perspetivas (2012). Access 19march 2016, <http://www.fara.edu.br/sipe/index.php/renefara/article/view/53>

[9] Ben-Ari, E. T., Better than a thousand words. Botanical artists blend science and aesthetics,BioScience.49(8), 602-608 (1999).

[10] Pamuklu, A. G. Botanical illustration in Turkiye,Global Journal on Humanites\& Social Sciences.1, 531-536 (2015).

[11] Oliveira, R. andConduru, R., Nas frestas entre a ciência e a arte: uma série de ilustrações de barbeiros do Instituto Oswaldo Cruz, História, Ciências, Saúde -Manguinhos. 11, 335 - 384 (2004).

[12] Silva, R., A ilustração nos livros de Botânica no séc. XIX: técnicas de reprodução da imagem a cores (2011). Access 28 march 2016, <http://www.esocite.org.br/eventos/tecsoc2011/cdanais/arquivos/pdfs/artigos/gt020-ailustracao.pdf >

[13] Miguel, S., Aquarelas botânicas de espécies nativas da região da Serra do Espinhaço (2012). Access 28 march 2016,<http://www.caleidoscopio.art.br/marciafranco/texto-sebastiaomiguel.htm>

[14] Correia, F. andFernandes, A., Desenhar para (Re) conhecer: o papel da ilustração científica nas missões científicas do espaço lusófono. Ata do Congresso Internacional Saber Tropical, História, Memória e Ciência, Moçambique. (2012).

[15] Kenny, J. S., The importance of illustration. Ezine Articles (2010). Access 29 march 2016, <http://ezinearticles.com/?The-Importance-of-Illustration\&id=5269590>

[16] Morato, M., Struchiner, M., Bordoni, E. andRicciardi, R.,Representação visual de estruturas biológicas em materiais de ensino,História, Ciências, Saúde-Manguinhos.5, 415-433 (1998).

[17] Swan, C., Illustrated Natural History, Cambridge Mass: Cambridge University Press.186-198 (2011).

[18] Pereira, R., Brasil Desconhecido - A ilustração botânica descobre a Amazónia e o Cerrado (2011). Access 30march 2016, <http://issuu.com/liximenes/docs/brasildesconhecido2>

[19] Blunt, W., The new naturalism - The art of botanical illustrations. $3^{\text {rd }}$ edition. Londres: Collins $14{ }^{\text {st }}$ Jame's Plance London, 1955. 
[20] Flannery, M. C., The closest of collaborations: botanical illustration, $27^{\text {th }}$ Annual National Conference on Liberal Arts and the Education of Artists: Collaboration in the Arts, New York City (2013).

[21] Secord, A., Botany on a plate: Pleasure and the power of pictures in promoting early nineteenthcentury scientific knowledge, History of Science. 93, 28-57 (2002).

[22] Peck, p. Scientific illustration in the twentieth-century. The artist in the service of science. Zurique: TheGraphicPress, 1973,38-57.

[23] Duarte, C., Padim, D., Epoglou, A. and Lima, V., A importância da História da Ciência na perspetiva de alunos do Ensino Médio: a investigação em uma escola no Pontal do Triângulo Mineiro, XV Encontro Nacional de Ensino de Química, Brasília,(2010).

[24] Duarte, C., Jayme, C., Epoglou, A., A História da Ciência e o livro Didático de Química: uma análise do conceito de equilíbrio químico,Anais do XVI Encontro Centro-Oeste de Debates sobre Ensino de Química, Itumbiara, (2009).

[25] McClintock, E., The Trees of Golden Gate Park and San Francisco. California: PacificHorticultural Foundation, 2001.

[26] Guisepi, R. A., Beginning and Progress of the Renaissance. Retrieved from International World History Project (2004). Access 31 march 2016, <http://history-world.org/renaissance.htm>

[27] Watkins, J., The Renaissance. Regents Prep: Global History- Golden Ages (2003). Access 31 march 2016, <http://www.regentsprep.org/regents/global/themes/goldenages/ren.cfm>

[28] Carneiro, R., Série de textos sobre ilustração botânica para divulgação em geral. Supernova (2002). Access 24 march 2016, <http://www4.netpar.com.br/dianacarneiro/main_refer_textos. html>

[29] Charmantier, I., Carl Linnaeus and the visual representation of nature,Historical Studies in the Natural Sciences.41(4), 365-404 (2011).

[30] Schmidt, A. M. and Jacoby, T. B., Herbs to Orchids: Botanical illustration in the nineteenth century, Watkinson Exhibition Catalogs. 4 (1): 1-21 (1996).

[31] Yates, S., Illustrated botanical books, fifteenth, sixteenth, seventeenth centuries. Ames: Special Collections Department, Iowa State University Library, 1974.

[32] Kusukawa, S., Leonhart Fuchs on the importance of pictures, Journal of the History of Ideas. 58 (3): 403-427 (1997).

[33] Fuchs, L., De Historia StirpiumCommentarii Insignes. 2 nd ed. Basileia: Apudbalthazaremarnolletum, 1551, 371p.

[34] Lonicer, A., Naturalis Historiaeopvsnovvm in qvotracta. Frankfurt. ApudChr,Egenolphum, 1551, 96p.

[35] Lusitano, A., IndexDioscorides, ioanneRoderi co Casteli Albi Lusitano autore. Leon:ApudTheobaldumPaganum, 1558, 183p.

[36] Mattioli, P., New Kreüterbuch: Mit den allerschönstenvndartlichstenFigurenallerGewechß, dergleichenvormals in keinersprachniean tag kommen. Praga: Georg Melantrich von Auentin, 1563, 74p.

[37] Portta, G., Phytognomonica Io. BaptistaePortae. Neapoli: HoratiusSalvianus, 1580, 152p.

[38] L'Écluse, C., Rariorumplantarum historia. Antuérpia: OfficinaPlantiniana ApudIoannemMoretumChristophoriPlantini,1601, 8p.

\section{AUTHORS' BIOGRAPHY}

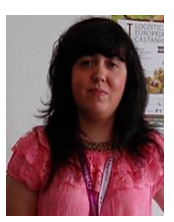

AndreiaMarliseCarneiro de Carvalho,Degree in Biology and Geology, master's degree in Biology and Geology teaching in the $3^{\text {rd }}$ cycle of basic education and secondary education. PhD student in Earth Sciences and Life, the perform research on the theme of chestnut.

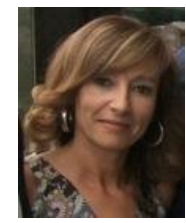

Isilda Teixeira Rodrigues,Assistant Professor attheUniversityof Trás-os-Montes and Alto Douro, Portugal. PhD in Education/History of Science.Published 27 articles in journals, 80 proceedings and 10 books and chapters. Works in Science Education, Health Education, History of Science and Didactics of Science. 